\title{
Redefining Resilience in Developed Cities: opportunities and challenges for the urban built environment as housing for a post-disaster population, Athens and London.
}

\section{Christina Kavoura}

University College London, Department of Geography; Aristotle University of Thessaloniki, Faculty of Architecture

christina.g.kavoura@gmail.com

Tel.: +44 7715563138

\begin{abstract}
This dissertation has aspired to examine resilience as a contemporary trend and popular discourse as well as its claimed relation with housing provision for the population that is displaced after a disaster and forced to migrate from their homes. My interest is focused on how Athens and London as proclaimed developed cities, have incorporated in their resilience frameworks the existing built environment and considered their capacity for the accommodation of these groups. My research is exactly around these frameworks of the two cases, which compose my cases studies and how their urban scape responds to the housing needs of the vulnerable population after a sudden or more persistent crisis. Interviewing experts and policy-makers as well as scrutinizing relevant official documents and reports was a way of delving into my field of study while comparing two cities that I am particularly interested in. The findings of the present research were particularly interesting. Connections that I could only suspect proved to be fundamental for the concepts of this paper as this of the city's governance, the established crisis and the interconnections of external groups of actors. In this dissertation I argued that the regulated concept of resilience in London has a lot to learn from the localized responses of Athens, while, at the same time, Athens can take a lesson from the well-coordinated and independent system that London applies in the housing of people affected by emergencies.
\end{abstract}

Keywords: urban resilience, post-disaster, displacement, housing, resilience framework, urban governance, Athens, London. 


\section{Introduction}

The multiregional humanitarian crises that have their origins either in natural hazards or manmade disasters are affecting millions of people around the world, often leading to their displacement. How cities respond to these crises and to the arising needs of their residents is my main focus. More specifically, I will focus on the way cities can be able to absorb the displaced population, with regards to housing and accommodation within the existing built stock and in the aftermath of any disaster. Migration, climate change and financial recession are some cases where the responses of resilience strategies would contribute to the mitigation of these crisis, protect the affected population from threats and risks, as well as improve their living quality.

Athens and London, perceived by their resilient strategies as these are declared in comprehensive resilience agendas, will be compared and contrasted with several factors being considered. The interest stems not only from personal concern, but also from my academic and professional experience in the context of crisis, emergency and displacement as an architect, urbanist and humanitarian worker. My close affiliation with the two cities renders this study a natural progression in exploring the two cases' capabilities and potentials in the realm of resilience. Starting from the context of the two case studies and considering the right to the city for the vulnerable population affected by disasters, these two urban cases portray distinctive characteristics, both weaknesses and potentials.

On a global, country, and city level, the two metropolises are currently advocating their resilience strategies against predicaments, accidents and disasters. Approaching crises from a generic point of view claiming that anything can happen anywhere, the following chapters are an analysis of my main concepts through the undertaken methodology (chapter 2). In chapter 3, I will develop the concept of resilience in each of the two cities according to my findings, and will further elaborate on how the urban governance constitutes a great factor in forging resilience strategies. A detailed focus on the housingrelated resilience adopted by Athens and London will take place in chapter 4, and includes an analysis of housing provision when immediate shelter is an imperative need. Finally, I will develop arguments on how responses to disaster, enacted or projected, satisfy the vulnerable. Civic society and its links with other institutions, governmental or non-governmental, as well as the scale of the shelter strategy varying from the regional-level ambitious mechanism of London, to the smaller neighborhood one in Athens, are some points to develop and critique both comparatively and independently through the research findings and conclusions.

With my research I aim to provide insights on the field of resilience, the actors and significant implicated bodies since the time the concept of resilience was introduced in the two cases. What is their response regarding the vulnerable groups' accommodation in situations of chronic stresses and/or shocks? Have they used their existing capacity? Answering these questions will contribute to identifying holes in the issue, add to the literature of resilience, and bring forward the relation of housing in Athens and London within their specific contexts and particularities. The way these cities can, through their similarities and differences, improve their responses and learn from one another is one of the challenges of this comparative study.

\section{Methods}

Throughout my research, I am undertaking various methods of collecting data. I interviewed four experts with specialized knowledge related to my fields of study, two for each case study, and both in 
the cities' local governments and the international institutions, policymakers from the City of Athens and London's authorities, as well as professionals on resilience from the 100 Resilient Cities organization. The interviews were semi-structured and adapted to the area of expertise of each individual. Moreover, the research draws information from a wide range of documentation relating to resilience strategies. This will include the official 100RC documents, governmental policies, local authority legislations and relevant international organization reports. To achieve a more holistic approach, I will refrain from comparing the policies line by line. Instead I will examine the post-disaster resilience of the cities based on past events where emergency response was, or should have been, implemented. The latter is considered to be an effective method of assessing and evaluating the data using the chosen methodologies, and gives credence and validity to the findings whilst also being an effective critique.

Lastly, following Mitchell's definition for the "city as a network of networks" (1973, cited in Robinson 2006) and aiming to unveil the connections and highlight the cities' diversities, I am adopting a comparative analysis of the resilience frameworks within the two different urban contexts of Athens and London during the early 00s. By studying the cities as relational historical and geographical contexts of development and identity (Massey 1993), I will critically engage with the compared systems and the researched cities to see how they can learn from one another, acknowledge and adopt other good practice examples (Janssen-Jansen, Spaans and Van der veen 2008).

\section{Athens and London seen through their resilience frameworks}

Scale and density are physical elements that vastly differentiate the two metropolises and are equally influential in the sustainability of each. Being a city of 4,5 million in its metropolitan area, the Athenian urban fabric appears to be massively denser than London's as a quantitative approach reveals that 7462 people $/ \mathrm{km}^{2}$ are found in Athens and 5518 people $/ \mathrm{km}^{2}$ in London (Versus 2018). Thus, the built environment, when compared to that of London, appears to be vastly homogenous, dense and formless (Dragonas 2014). In Athens this was mainly driven not by a masterplan or urban design principles, but by the property tax and legal code (The Hackable City 2018) and was expanded to cover the housing needs of the post-war rural-urban migration for employment opportunities. The product of these tactics was a misinterpreted, postmodern, multistory housing typology; the polykatoikia ${ }^{\mathrm{i}}$, which was blooming during the 50s, 60s and 70s and constitutes the main structure of the built environment in Greece. During the same time frame, London was developing strategies to accommodate the portion of the population made homeless by World War II (Cherry 1988). The initiatives and responsibility stemmed from the public sector (ibid.) and not from developers-investors as in Greece and, as a result, an intensive erection of estates and high-rises started.

Despite the excessive need for it, the concept of social or affordable housing is not part of housing policy in Greece, whereas this terminology is widely used and developed in London, which was the first city to implement this ideal after the 40s. These differences, when first viewing a city, are only first part of a wider context which illustrates greater differentiations, not only in form and typologies, but also in the financial, political and social status of the case studies. The polykatoikia reflects a lot of the social homogeneity of the residents that occupy it. This has led to inequalities spreading over the city in a horizontal manner, and the stratification to diffuse in the ' $\mathrm{x}$, neighborhood axis. On the other hand, London and its longer history of urbanism presents more profound 
variations in the streetscape, as one can be confronted with multiple typologies that confess the accommodated status quo. High-rise buildings, initially for the low-income groups and designated social housing, co-exist with high-class historic or contemporary accommodation. This differentiation encompasses a major indication of a city's capacity to respond to any challenge, crisis or accident and to absorb those in need.

Nesting in these environments, different types of crises are currently striking the two cities. From the stance of an urbanist, the financial recession in Greece has majorly affected living conditions and levels of competency in Athens, and elsewhere in the country, worsening the high rates of unemployment and poverty. Confining crisis to a more explicit sector, Madden and Marcuse (In Defense of Housing: The Politics of Crisis 2016) critically engage with one of the major issues in the UK; the housing crisis, its causes and impacts. In a Marxist vocabulary, attention is paid to the politics behind displacement, homelessness and affordability that affect the egalitarian accommodation. Similarly, Minton (Big Capital: Who Is London 2017) develops the same debate around landownership, property statuses and community downgrading, which reveals another gap between the two cases. In the list of home ownershipii, Greece attains a high position, whereas London land is an asset only for the privileged and complies with the complicated procedures of freehold and leasehold.iii Of course, these well-established crises have been the basis for several in-situ alterations, smaller in scale but equally aggravating

\subsection{Addressing major urban governance differentiations}

Highlighting the crucial role of urban governance to the theory and practice of urban resilience, it is deemed important to describe the structure of governance in the two capitals, as this affects implementation and performance. In London, after Thatcher's abolition of the Greater London Council in the 1980s, the city was under the jurisdiction of parliament (Goldsmith 2001). The need for a diffusion of power was reflected in 2000, when the Greater London Assembly was founded and, along with the Mayor, they now compose the Greater London Authority (GLA) (Pimlott and Rao 2004). Remembering the traditional British model of governance (Goldsmith 2001), the introduction of the GLA brought about further decentralized strategies (Pilgrim 2006). As the GLA's main responsibility is the delivery of the mayoral strategies (Travers 2002), the 33 boroughs compose the local government (Sweeting 2002) which is responsible for the localized implementation of the schemes (Pilgrim 2006). Despite the close collaboration for regional interests and the sometimes-conflicting responsibilities, the boroughs have a certain independence and, along with the Mayor and the GLA, compose the government of London.

Athens consists of 24 municipalities that compose the metropolitan area of Attica, containing more than 4 million citizens. However, the Athenian area is not understood as a metropolitan whole because of the lack of a greater authority that would govern and coordinate the metropolis (Beriatos 1998). Translating this into the resilience framework, means that only one out of the 24 municipalities, the City of Athens, was eligible to apply for participation in the 100 Resilient Cities program. On the other hand, the London that is represented by the GLA that includes all 33 boroughs. To give this numerical scale, the single municipality of Athens homes 660.000 registered citizens, and is the only one among the 24 others that adopted a resilience strategy. In London terms this would mean that the boroughs of Camden, Westminster and Kensington have a resilience strategy together, not including the rest of London. 


\subsection{Origin of the British and Greek Resilience Strategies}

The term was introduced in the UK in 2004 as a planning solution to terrorist attacks and the establishment of activities of preparedness (J. Coaffee 2013). With civil protection being the goal (Oldham and Astbury 2017), the events of 9/11 in New York, and the attacks that followed in other parts of the US, resulted in the writing of the Civil Contingencies Act 2004 (CCA) (Cabinet Office, Civil Contingencies Act 2004 2004), where resilience acquired the meaning of preparing for emergencies (London Resilience Team Manager 2018). More specifically, the Act is national legislation, aiming for local empowerment (Cabinet Office, Preparation and planning for emergencies: responsibilities of responder agencies and others 2013a) and bringing together organizations, enabling them to work collaboratively towards the aim of becoming a more resilient country (London Resilience Team Manager 2018). The CCA emergency planning contains incidents that can affect humans, the environment or the security of the UK (Cabinet Office, Civil Contingencies Act 2004 2004). To unite the plans of the boroughs, under the brief of the CCA, an overseeing team is introduced to provide a more collaborative approach and works as a shared knowledge platform and a resource of management practice (Sellberg, et al. 2018). The team active in London is the London Resilience Team (LRT) (London Resilience Team Manager 2018).

The respective chronicle in Greece is far simpler. According to the Communications \& Stakeholder Engagement Manager of Resilient Athens (100 Resilient Cities 2018), in 2014 the city applied to be part of the 100 Resilient Cities program, funded by the Rockefeller Foundation, and followed three steps up to June 2017, when the city released the Athens Resilience Strategy for 2030. As a member of the 100RC platform, the municipality of Athens was granted permission to create a team, produce, and implement the resilience strategy (Municipality of Athens, 100 Resilient Cities 2016). At the time of this research, Athens was in the third and last stage of implementing the goals set out (Communications \& Stakeholder Engagement Manager 2018). According to Athens Vice Mayor of migrants and refugees (City of Athens 2018), the concept of resilience was introduced in the country through this program, and wasn't known beforehand either as a notion or as a practice.

Resilience in UK is an institutionalized framework, the CCA (Cabinet Office, Civil Contingencies Act 2004 2004). This stems from the national government and is primary statutory document whereas At the time of research, Greece had developed no national legislation for emergencies and no contingencies. The long engagement of the UK with disaster management and emergency response has highlighted Greece's respective lack of resilience framework, which results in a weakness of the local authorities to coordinate, act and be effective. the resilience project in Athens is mainly attached to 100RC incorporating preexisting actions (Associate Director of 100 Resilient Cities 2018) at a local and more spontaneous level of practice. This way, Athens adopts a different approach to the concept of resilience that is intertwined with sustainability, rather than emergency.

\subsection{Discussion}

Identifying the origins, directions and meanings behind the concept of resilience in the two capitals reveals the mentality in each towards preparedness and swift recovery. While in Athens the concept acquired a more environmental approach, with neighborhood scale actions and local coalitions, the term emergency is of greater importance in London. British administration forges the city's ability to adapt 
and respond, solidifying the parameters and entrenching the unforeseen possibilities. Considering this, it is true that very large-scale planning is unfolding. The Resilience Partnership brings together a vast number of actors, developing a "mega-project" (Fainstein 2013, 14), and promoting an ambitious managerial design. The concept of resilience seems to be related closely, if not solely, to policy making across political authorities, national and urban, as well as security services such as the police, and at times the army, who have held a heavy presence in all past threats and disasters.

Following Beck's risk society (Risk Society, Towards a new Modernity 1992) and the fortification project, there is a clear lack of multi-disciplinary inclusion. To agree with Coaffee (Terrorism, Risk and the Global City: Towards Urban Resilience 2009) and Godschalk (Urban Hazard Mitigation: Creating Resilient Cities 2003) regarding the engagement of urbanists in the process and outcome of resilience "if we are to take the achievement of urban resilience seriously, we need to build the goal of the resilient city into the everyday practice of city planners, engineers, architects, emergency managers, developers and other urban professionals" (ibid. p. 142). To this end, I will also add the employing of citizens and built environment professionals. This way, tangible issues outside securitization and service delivery, will cover the gaps left by governance and policy making, while considering multiple levels of resilience. To paraphrase Harvey (Capital links: urban eco-resilience in the face of capitalist power structures 2017), it is the representation of rights that matters more than the unerring strategy, referring also to the power structures of the stakeholders. This argument is a nod towards the combination of theory and practice, and denotes the importance of considering the socio-political nature of resilience.

The narrowing of London's focus to the resilience of the community and the individual in several policy papers $^{\text {iv }}$ is relevant to this argument, as they are both considered active (Chandler 2012). This was framed in the Borough Emergency Plans, explained previously. The need for a democratic dialogue intrudes into the discussion of adaptability of both community and individual, and it can be identified in Athens' approach to bring together localized actions taken from neighborhood forums and collective creative groups. In the first case, local government is both the content and the container, while in the Greek capital the local governments are collaborating with international institutions to frame the dangers that pertain a threat to both the urban fabric and the person itself, factors that lead to some of the latest views from urban theorists.

\section{Housing Resilience}

A term that goes beyond the categorization of housing in emergency, temporary and permanent (Kreimer 1979) but also related to time, is that of immediate housing. By this, I refer not the type of accommodation in structural terms, neither the recourse of a humanitarian refuge rather the urban capability -social, political and infrastructural- to provide shelter to the victims of disasters, as laid out in previous chapters. Drawing on the resilience definition and the political responses themselves, immediate housing is a resilient indicator since it assigns an equilibrium after a mass disruption in the city's environment. The close relation of housing as shelter with the resilience index in Athens and London prove the high trends of the displaced population and the need for sheltering at the time this need appears.

\subsection{Forms of immediate housing in resilience policy context}


"Shelter provision will be required following an evacuation, or there may be a need to support people who have been advised to shelter in place. Shelter focuses on the short term (up to 72 hours) [...]. Medium-term (weeks or months) shelter is likely to be needed for smaller numbers, but evacuees may need help with accommodation, access to insurance companies, welfare, schooling, employment and access to services" (Cabinet Office, Evacuation and Shelter Guidance 2014, 6).

Considering the legislative frameworks, international initiatives and the interviewees' responses, the emergency plans of both Athens and London approach immediate housing with various interpretations. London's Resilience team, as the author of the main response documentation on accidents and shocks, has produced the London Mass Evacuation (London Mass Evacuation Framework 2014) and Mass Shelter Frameworks (London Mass Shelter Framework 2014) and these constitute the basis of specific emergency plans ${ }^{\mathrm{v}}$, who are the ones to consult when an emergency occurs in the form of a shock. The two frameworks are providing instruction on the type of housing that should be available. According to their description, they are activated when the sudden onset incident (a term in chapter 1 set as shock) exceeds the capacity of the borough emergency plan in terms of the population that has been displaced, and the scale of the incident. Short-term and long-term accommodation are framed as belonging to the response and recovery work respectively, with relevant Coordination Groups to be created while transitioning from one to the other.

The types of immediate housing, according to the Manager of the LRT (ibid.) are "hotels, gyms, church halls, some are formal, run by the council [...] or informal [...] and then the council or the agency has to liaise with that place". The interviewee also refers to the period after the short-term housing, mentioning that "the theory is that they should be absorbed in the normal housing system [...] but of course there is a shortage of housing and there are many people on the housing list".

The mass arrivals and recurrent phenomena of continuous displacement has rendered the seeking of accommodation important. However, the shocks that occurred in the city were not treated as organized. Adding to this, and drawing on the Athens Resilience Strategy for 2030 (Municipality of Athens, 100 Resilient Cities 2016), an important difference for housing after a disaster, would be that the Greek approach is based on chronic stresses or shocks that take place in everyday life and become permanent. This fact affects the type of response and is reflected in the resilience attitude of each country. Other factors contribute to this, such as history, scale and politics, and are equally responsible for the shaping of the two approaches that are critical for a population that is displaced. This difference is well reflected in the approach to empty homes as accommodation for the vulnerable groups, which is strategically planned in Athens and there is a clear request for this to become the case in London.

\subsection{Informal housing and empty homes}

Comerio (Housing Issues in Future US Disasters 2004) connects a city's existing empty homes with immediate housing in a very straightforward way claiming that "in Los Angeles, sheltering was not a difficult problem because the economic recession had caused high vacancy rates (8-9 percent) in rental housing throughout the area. By contrast, in Kobe, rental vacancies were extremely low, and 316,000 people were housed in evacuation shelters after the event." This argument has been included in the Strategy for Resilience Athens (Municipality of Athens, 100 Resilient Cities 2016):

"The city in collaboration with the central government should create a program to provide social housing in empty buildings of Athens in a diverse group of vulnerable populations and beneficiaries. 
The system should be based in a strict and fair model of evaluation of the beneficiaries based on meritocracy in order to justify the selection of the people and the implementation of the project." (p.178)

Indeed, vacant buildings are considered to be a great opportunity for Athens' authorities. Seen as an urban asset, high vacancy rate is planned to be capitalized upon and supported by actions within the boundaries of the Municipality of Athens, and in collaboration with international assistance, including those in the resilience planning. It is a way of assisting those displaced by a disaster but also has its value in the chronic financial crisis as a kind of stress which, as mentioned previously, is the most severe crisis in the country.

Similarly, the empty property discourse is very intense in the housing crisis debates in London, especially post-Grenfell. Reactions brought up the issue of the 'buy to leave' tactic ${ }^{\mathrm{vi}}$, addressing questions to the GLA asking for quantitate data on the number of flats either underused or vacant for a considerable amount of time. The extract below (Gleeson 2017) shows the response of the GLA and the Senior Policy Officer of Housing in London:

"Dear,

According to official statistics published by the Department for Communities and Local Government [...] there were 58,096 empty homes in London in October 2016. The Mayor has recently commissioned research to understand the impact of overseas buyers on London's housing market, including the extent of so-called 'buy to leave'. The results of this research should be available soon and the Mayor will respond to it in due course."

Several arguments and reports have been produced on this sensitive, yet crucial, issue for London. Edwards (Prospects for land, rent and housing in UK cities 2015) claims that the delivery of housing has not been proportional to the needs of the rising population, rendering the land value, and consequently the housing prices, unaffordable. Housing in London is a luxury asset, and various proposals have been formally or informally submitted towards its full leveraging. London Assembly member, Harmood, has suggested the taxation of empty properties in the context of the massive housing crisis in the city, homelessness and the wake of Grenfell fire (Buchan 2017). This implies that adding more built stock to the housing market will proportionally increase the percentage of social, or else affordable, housing in London. According to the Associate Director of 100RC London (100 Resilient Cities 2018), the lack of the latter is a source of the severe social inequalities, indicates low resilience and is rooted in the housing regime of the city for reasons explained in the introduction.

\subsection{Welfare and housing}

Following the last argument, it's worth mentioning that the consideration of the vacant apartments in Athens Resilience Strategy (Athens Resilience Strategy for 2030 2016) is placed in the Social Housing Program chapter, which connects the provision of emergency and post-disaster accommodation with social provision and vulnerability. This renders the country's welfare a crucial factor in the provision of immediate shelter and an indicator of resilience. Indeed, the growing power of the local government, as was revealed in chapter 3 , has proven that the latter carries a heavy weight of responsibility for social provision (Paddison 2001).

It is true that Southern European cities have weak social housing policy (Allen, et al. 2004). This weakness reflects the inability of a city to respond in an organized way to accommodation needs, further reflected by the type of housing offered for the displaced population and, hence, indicates the level of its resilience. Greece never had a housing policy, let alone a social housing base (Emmanuel 2006), as 
the system and strong established tradition of the country is a spontaneous practice rather than a wellorganized tactic (Vice Mayor of migrants and refugees 2018). Moreover, to the advantageous ownership status where, as mentioned in the introduction, Greece acquires a high position, is added the taboo of social housing residents, as described by Cowan and McDermont (Regulating Social Housing: Governing Decline 2006) who argue that "social housing is an arena for regulation" (Regulating Social Housing: Governing Decline, xii). This argument links welfare and social housing with the Foucauldian notion of governmentality providing a more specific framing for what Reid (Interrogating the Neoliberal Biopolitics of the Sustainable Development-Resilience Nexus 2013) calls "the biopolitics of resilience" (Interrogating the Neoliberal Biopolitics of the Sustainable Development-Resilience Nexus, 356). At this point, ideas on the resilient subject and the politics behind it, as analyzed in the previous chapter, meet the above perspective on housing resilience.

\section{Discussion}

As the previous chapters have indicated, the two capitals have been affected by a wide variety of actors, whose fields span from international, to local and neighborhood ground. During the interviews, several examples of specific cases of displacement have been broached. This facilitated the flow of the conversation as it allowed a common frame of reference and a layer of grounding in reality. Although this research does not constitute a study of these particular events, some of them will be used to facilitate the comparison and ground things to real time events and responses. This has led me to revisit the scales of resilience, analyzed in a previous chapter, and critically engaging with the planning systems and scheme, while examining the effect of some main concepts, proved crucial throughout the research of this governmentality and mega-project planning approach.

\subsection{Views on specific crisis responses}

The example of Grenfell was frequently broached during the interviews due to the need of a resilient response in terms of housing. This, and the precautionary evacuation of Chalcot Estatevii that took place in another London neighborhood in the immediate aftermath of Grenfell, were cases of large scale and the implicated actors included central government, local authorities (the boroughs), LRT and emergency services (London Resilience Team Manager 2018). The type of immediate housing chosen for both sudden and scheduled displacements was predominantly hotel accommodation. "The temporary accommodation being provided by the council includes two rest centres, hotels and student halls of residence." (Quinn 2017). However, the period of temporary hotel accommodation has been lengthened to over a month and, in some cases, for almost a year (Press Association 2018).

As for Athens, the camp of Eleonas, property of the municipality and the city of Athens itself, accommodates approximately 15,000 refugees (Vice Mayor of migrants and refugees 2018). In addition to this, several accommodation centres and inappropriate spaces were also used including squares and derelict buildings (ibid.). My personal professional experience has indicated that empty parcels, abandoned industrial spaces, as well as underused army camps, could be used as the emergency destination for the inflow of foreign refugees. The UNHCR funded Urban Housing Project is one example that implemented, through NGOs, an innovative program where urban accommodation was 
encouraged by renting empty flats for the benefit of the refugee population residing in camps and following a priority of vulnerability for their transfer.

My research in Athens and on past disasters in Greece has proven the absence of emergency planning and preparedness. The lack of experience in collaboration between actors has led to the consequential delay of housing delivery and, as a result, the unsafe and unsecure settlement of the displaced (Johnson 2007). The regional administration was not prepared for large or small-scale disasters, for reasons explained in previous chapters, that left a considerable portion of the population, both local and foreign, homeless, leading to the perpetuation of their transition time back to normal living and leading to actions based on haste and confusion (Aktipis 2016). Assuming that these low levels of resilience are highly dependent on the above indicators, one would come to the conclusion that a reverse trend would mean the adequate provision of immediate housing and the resilient response by the local authorities. However, examples such as Grenfell fire and the similar high-rise evacuations did not confirm this assumption about the respective delivery of shelter homes, proving otherwise for London's regulated resilience.

\subsection{Resilience scales revisited}

In both research cases, when it comes to immediate housing of a displacement population have to overcome their own difficulties. Athens, devoid of resources as it is, has to fight the inefficient leadership that led to the high extent of dependence on international aid due to the structure of funding, donations distribution and urban governance on one hand, and the dominant role of civil society engagement in the absorption of the incoming displaced population in the built environment on the other. Following this logic, UNHCR, several international NGOs, and local organizations understood the peculiarities of the Greek built environment. However, the above-mentioned weakness of the Greek governance to imbed in its system issues of displacement and house provision has also been led by fragmented decision making, inconsistent planning, temporary results and slow implementation. Humanitarian organizations played an important role in setting the standards for human settlements in emergencies globally. This fact is also a political approach that defines the type of response the city adopts. In the case of Athens, and Greece in general, the UN had an active role throughout the burst of the refugee crisis and the influx of homeless population, as Athens didn't have any previous references in its legal and executive system while demonstrating stiffness and lack of housing policies for the incoming population (Gemenetzi and Papageorgiou 2017).

Self-organization and the civil society potentials are revealed when considering the struggles of Athens's financial and displacement crisis of recent years. It is true that the levels of resilience and immediate housing don't seem to have differentiated after the establishment of the 100RC program in Athens. Instead, the globalized approached of the organization has overlooked the on-the-ground reality including existing culture diversities, politics and power structures (Tanner, et al. 2015) although based in the existing urban networks. Towards this argument, Davoudi (Resilience: A bridging concept or a dead end? 2012) is confirming the outcomes smaller changes can have in the system, in this case the cities, while condemning the effectiveness of readymade toolkits for responding only to past circumstances.

As for London, the pushing forces of neoliberal practices have their own benefit interests, and lean upon the city's high capital accumulation. The dependence, seen in several cases across the city, on governmental and regulatory guidance stood opposite to the individual. The large institutional bodies, 
ambitious planning schemes and mega projects did not deliver the appropriate results in cases of emergency, and failed in times of crises. The role of the homeless, displaced subject (Grocock 2008) stands on the other side of that of the resilient subject. As Flint (Social Housing Agencies and the Governance of Anti-social Behaviour 2002) contends the housing agencies are "exerting disciplinary power through authoritarian measures" (Social Housing Agencies and the Governance of Anti-social Behaviour, 635). Similarly, one can argue that in the examples mentioned, as well as in a wider scale of incidents in the country, authoritative power and regulation to the level of the individual was very present, and cannot be disassociated with their relation to resilience.

On the whole, the strategies, plans and approaches described in previous chapters indicate that there are further, more complex and focused reasons why rehousing schemes fail, rather than the dearth of built stock, inappropriate built environment and unit scarcity. Since housing is not a vague concept to be restricted to academic debates, the relation of theory and practice becomes crucial. As an asset of luxury in London, and as ownership is traditionally a status sign in Athens, housing is strongly associated with economic status, wealth and materiality, and connected with unjust policy making (Flanagan 2015). As such, immediate housing in London is rendered more a matter of resourcing and corporative businesses rather than a human right, and central authority responsibility resides in all scales of resilience, while in Athens it is well rooted in the citizens' good will, and the external funding that assists temporary settling and foreign aid, instead of in the city itself. I argue that is an imperative need, in both cases, to overcome these difficulties and readdress "how interactions between systems and local practice play out in the concrete terrain of housing systems in a post-disaster urban environment" (Porter, Steele and Stone 2018, 6). (Cabinet Office, Emergency Preparedness 2012)

\section{Conclusions}

This research aimed to explore the housing provision of Athens and London for the displaced population through the concept of resilience. In order to understand the relation of theory and practice of the resilience agendas of the two cities, I explored the policy papers the relevant actors have produced, as well as interviewing experts that represent the current stances across the two cities and affect their actions in cases of emergencies and crises. Additionally, I incorporated views of significant thinkers familiar with the topic of resilience, disaster and displacement, as well as timeless personalities that have influenced the aforementioned and forged both my point of view and my political position. Of course, the above were enlightened by the comparison of the two capitals and considered in parallel, yielding the studies useful conclusions, and helped develop my critical thinking throughout the study.

As a research is a dynamic and interactive process, the initial concepts are changeable and open to addition. Although the research questions remained the same throughout, the lenses and layers were adapted to the findings and the outcomes of the study. Starting with the concept of resilience itself, contested as it is (Shaw 2012), I argued that it is a vital one for the cities. Although having been associated with control and nonlinearization, resilience as a mentality can contain useful guidance on how to cover human needs in cases of emergency, both shocks and stresses, and assist local authorities in adapting and surviving crises. This way, a city can come a step closer in providing their residents the right to accommodation when the need arises providing shelter.

It has been proven from this paper that for a population to be absorbed into the existing urban fabric and embedded in the planning system, the development of the resilient concept is not enough. Urban 
governance, politics, funding mechanisms, pre-established class struggles, order and social inequalities are crucial factors in the equation of resilience. All the above suggest that both cities, in order to guarantee their level of disaster management, should engage more in the way their policies reflect on their responses, as a clear gap between the two has been identified through the examples that were examined.

Although the resilience strategies of the cities include housing provision for the displaced, the connection remains problematic. London's approach on resilience has proven to be well-based on these policies produced by the national and local government, including emergency services and specific responses, while Athens' in situ reactions are in most cases spontaneous, precipitate, less dependent on the city's own capacity and merely triggered by international aid. The above characteristics can constitute lessons for both cases towards the problematic of "resilience from what, to what and who gets to decide?" (Porter, Steele and Stone 2018, 5). This research, as a comparison of these realities, has indicated the need to rethink the scales of resilience, to guide through the large number of implicated actors and to narrow the gap between knowledge and action. 


\section{Acknowledgments}

I would like to thank my dissertation supervisor, Dr. Jonathan Rokem, for his intellectual and psychological support throughout the process as well as for leading the class of City, Space and Power during the first term that critically influenced my point of view of studying the urban.

I would like to thank also my interviewees for the time they dedicated me and helping my research with the valuable information they provided me.

A big thanks to all the contributors of the Urban Studies course, from academics to my course mates, for the inspiring year and discussions towards a better world.

Lastly, I would like to thank my family and my friends, Virginia Giagkou, Marilia Kaisar, Oriana Romero and Elias Economakis, for the endless support through the difficult times during this year.

\section{Conflict of Interest}

"The authors declare no conflict of interest"

\section{References and Notes}

Journal Articles:

- Aktipis, Herakles. 2016. "The refugees in the doorstep of EU: Human rights "under negotiation"." Entha 1 (5): 7-10.

- Chandler, David. 2012. "Resilience and human security: The post-interventionist paradigm." Security Dialogue 43 (3): 213-229.

- Coaffee, John. 2013. "Rescaling and Responsibilising the Politics of Urban Resilience: From National Security to Local Place-Making." Politics 33 (4): 240-252.

- Davoudi, Simin. 2012. "Resilience: A bridging concept or a dead end?" Planning Theory \& Practice 13 (2): 299-307.

- Dragonas, Panos. 2014. "An Obituary for the Greek City of Repetition." Mas Context (21): 8297.

- Fainstein, Susan. 2013. "Resilience and justice." MSSI Research Papers Series (Melbourne Sustainable Society Institute) 2: 1-18.

- Flanagan, Kathleen. 2015. "A Genealogy of Public Housing Production." Housing, Theory and Society 32 (4): 407-428.

- Flint, John. 2002. "Social Housing Agencies and the Governance of Anti-social Behaviour." housing Studies 17 (4): 619-637.

- Gemenetzi, Georgia, and Papageorgiou, Marilena. 2017. "Spatial and social dimensions of housing policies for the immigrants and refugees in Greece: a critical review." Social Research Survey 148 (A): 1-30. 
- Godschalk, David. 2003. "Urban Hazard Mitigation: Creating Resilient Cities." Natural Hazards Review 4: 136-143.

- Goldsmith, MIchael. 2001. "Urban Governance." In Handbook of Urban Studies, edited by Ronan Paddison, 325-335. London : Sage.

- Grocock, Anne. 2008. "Foucauldian principles and issues of homelessness." Occasional Working Paper Series 1 (1): 1-22.

- Harding, A. 1994. "Urban regimes and growth machines: Towards a cross-national research." Urban Affairs Quarterly 29 (3): 356-382.

- Johnson, Cassidy. 2007. "Strategic planning for post-disaster temporary housing." Disasters 31 (4): 435-458.

- Kreimer, Alcira. 1979. "Emergency, temporary and permanent housing after disasters in developing countries." Ekistics 46 (279): 361-365.

- Meerow, Sara, and Joshua Newell. 2016. "Urban resilience for whom, what, when, where and why?" Urban Geography 1-21.

- Pilgrim, Martin. 2006. "London Regional Governance and the London Boroughs." Local Government Studies 32 (2): 223-238.

- Pimlott, Ben, and Nirmala Rao. 2004. "Metropolitan Miasma: Blurred Accountabilities in the Governance of London." The London Journal 29 (2): 33-45.

- Porter, Libby; Steele, Wendy and Stone, Wendy. 2018. "Housing and Resilience: When, for Whom and for What? A Critical Agenda." Housing, Theory and Society 1-7.

- Reid, Julian. 2012. "The Disastrous and Politically Debased Subject of Resilience." Development Dialogue 58: 68-80.

- Reid, Julian. 2013. "Interrogating the Neoliberal Biopolitics of the Sustainable DevelopmentResilience Nexus." International Political Sociology 7: 353-367.

- Robinson, J. 2016. "Thinking cities through elsewhere: comparative tactics for a more global urban studies." Progress in Human Geography 40 (1): 3-29.

- Robinson, Jennifer. 2011. "Cities in a World of Cities:The Comparative Gesture." International Journal of Urban and Regional Research 35 (1): 1-23.

- Sellberg, M, P Ryan, S Borgstrom, A Norstrom, and G Peterson. 2018. "From resilience thinking to Resilience Planning: Lessons from practice." Journal of Environmental Management 217: 906-918.

- Shaw, Keith. 2012. "The Rise of the Resilient Local Authority?" Local Government Studies 38 (1): 281-300.

- Stainsby, A. 2012. "Emergency planning and the UK Civil Contingencies Act 2004." Municipal Engineer 165 (ME2): 69-71.

- Sweeting, David. 2002. "Leadership in Urban Governance: The Mayor of London." Local Government Studies 28 (1): 3-20.

- Tanner, Thomas, David Lewis, David Wrathall, Robin Bronen, Nick Cradock-Henry, Saleemul Huq, Chris Lawless, et al. 2015. "Livelihood resilience in the face of climate change." Nature Climate Change 5: 23-26.

- Travers, Tony. 2002. "Decentralization London-style: The GLA and London Governance." Regional Studies 36 (7): 779-788. 
- Ward, Kevin. 2010. "Towards a relational comparative approach to the study of cities." Progress in Human Geography 34 (4): 471-487.

Books and Book Chapters:

- Allen, Judith, James Barlow, Jesus Leal, Thomas Maloutas, and Liliana Padovani. 2004. Housing and Welfare in Southern Europe. Oxford: Blackwell.

- Beck, Ulrich. 1992. Risk Society, Towards a new Modernity. London: Sage.

- Beriatos, Elias. 1998. Organisation and operation of the administration and metropoliatan areas management bodies. University of Tehssaly, Department of Planning and regional Development.

- Cherry, Gordon:. 1988. Cities and Plans, the shaping of urban Britain in the nineteenth and twentieth centuries. London: Edward Arnold.

- Coaffee, John. 2009. Terrorism, Risk and the Global City: Towards Urban Resilience. Surrey: Ashgate.

- Cowan, David, and McDermont, Morag. 2006. Regulating Social Housing: Governing Decline. New York: Routledge.

- Emmanuel, Dimitris. 2006. "The Social Policy of the Residence in Greece: The Dimensions of an Absence." National Center for Social Research (2).

- Janssen-Jansen, Leonie, Marjolein Spaans, and Menno Van der veen. 2008. New instruments in spatial planning: An international perspective on non-financial compensation. Edited by Marjolein Spaans, Menno van der Veen Leonie Janssen-Jansen. Amsterdam: IOS Press.

- Madden, David and Marcuse, Peter. 2016. In Defense of Housing: The Politics of Crisis. London: Verso.

- Massey, Doreen. 1993. "Massey, D. 1993: Power-geometry and a progressive sense of place." In Mapping the futures: local cultures, global change, edited by J Bird, B Curtis, T Putman, G Robertson and L Tickner, 59-69. London: Routledge.

- Minton, Anna. 2017. Big Capital: Who Is London. London: Penguin.

- Paddison, Ronan. 2001. "The City as Organised Polity." In Handbook of Urban Studies, edited by Ronan Paddison, 323-324. London: Sage.

- Robinson, Jennifer. 2006. Ordinary Cities, Between Modernity and Development. London: Routledge.

Policy papers:

- 100 Resilient Cities, and City of Athens. 2016. Global Migration, Resilient Cities at the Forefront. Athens: 100 Resilient Cities.

- Cabinet Office. 2004. " Civil Contingencies Act 2004." Accessed June 20, 2018. http://www.legislation.gov.uk/ukpga/2004/36/contents.

—. 2003. "Dealing with Disaster (rev. 3rd edn)." London: Cabinet Office.

- 2012. " "Emergency Preparedness." Accessed July 22, 2018. https://www.gov.uk/government/publications/emergency-preparedness.

-. 2012. "Emergency Preparedness." March. Accessed July 22, 2018. https://www.gov.uk/government/publications/emergency-preparedness. 
—. 2013b. "Emergency response and recovery." February 20. Accessed July 14, 2018. https://www.gov.uk/guidance/emergency-response-and-recovery.

—. 2014. "Evacuation and Shelter Guidance." January. Accessed July 29, 2018. https://assets.publishing.service.gov.uk/government/uploads/system/uploads/attachment_data/file/2 74615/Evacuation_and_Shelter_Guidance_2014.pdf.

—. 2013a. "Preparation and planning for emergencies: responsibilities of responder agencies and others." February 20. Accessed June 23, 2018. https://www.gov.uk/guidance/preparation-andplanning-for-emergencies-responsibilities-of-responder-agencies-and-others\#the-civilcontingencies-act.

- Greater London Authority. n.d. London Prepared. Accessed July 29, 2018. https://www.london.gov.uk/about-us/organisations-we-work/london-prepared/about-londonprepared.

- Edwards, Michael. 2015. Prospects for land, rent and housing in UK cities. London: Government Office for Science.

- London Resilience Forum. 2016. London Resilience Partnership Strategy. London: London Resilience Forum.

- London Resilience Team. 2014. London Mass Shelter Framework . London: Grater London Authority.

- Municipality of Athens, 100 Resilient Cities. 2016. "Athens Resilience Strategy for 2030."

Personal communication:

- Vice Mayor of migrants and refugees. 2018. City of Athens (June 11). (interview)

- Communications \& Stakeholder Engagement Manager. 2018. 100 Resilient Cities (June 12). (interview)

- Associate Director of 100 Resilient Cities. 2018. 100 Resilient Cities (July 13). (interview)

- London Resilience Team Manager. 2018. (June 24). (interview)

- Mayor of London Ofiice. 2018. Finance and Governance team (July 18). (email contact)

Conference Proceedings:

- Comerio, Maria. 2004. "Housing Issues in Future US Disasters." Vancouver: World Conference on Earthquake Engineering.

- Oldham, Kathryn, and Astbury, Karl. 2017. "Evolution of disaster risk governance in Greater Manchester: a case study from the UK." Bangkok: 7th International Conference on Building Resilience.

Websites: 
- Buchan, Lizzy. 2017. Budget 2017: Local authorities will be able to charge a 100\% premium on council tax on empty housing. Accessed July 22, 2018. https://www.independent.co.uk/news/uk/politics/budget-2017-housing-local-authoritiescouncil-tax-empty-properties-100-per-cent-premium-a8069511.html.

- Gleeson, James. 2017. "Homes in London and Empty Properties." May. Accessed May 2, 2018. https://www.london.gov.uk/about-us/governance-and-spending/sharing-ourinformation/freedom-information/foi-disclosure-log/foi-homes-london-and-empty-properties.

- Harvey, David. 2017. Capital links: urban eco-resilience in the face of capitalist power structures. Accessed June 20, 2018. http://urbandemos.nyu.edu/capital-sinks-urban-ecoresilience-in-the-face-of-capitalist-power-structures/.

- London Resilience Team. 2014. London Mass Evacuation Framework. London: Greater London Authority. Accessed June 23, 2018. https://www.london.gov.uk/about-us/organisations-wework/london-prepared/planning-emergencies-capital.

- Press Association. 2018. Grenfell Tower: more than $£ 20 m$ spent on survivors' hotel accommodation. Accessed May 28, 2018. https://www.theguardian.com/uknews/2018/mar/20/grenfell-tower-survivors-hotel-accommodation-rbkc.

- Quinn, Ben. 2017. Camden officials evacuate residents from fire-trap tower blocks. Accessed August 13, 2018. https://www.theguardian.com/uk-news/2017/jun/24/camden-officialsevacuate-tower-block-residents.

- The Hackable City. 2018. "The Hackable City International: Lessons from Athens, São Paulo and Shenzhen." Edited by Martijn \& Michiel de Lange de Waal. Accessed June 20, 2018. http://thehackablecity.nl/wp-content/uploads/2018/03/05dc59-Cahier-3-NAM-ev_.pdf.

- Versus. 2018. Athens vs London: 55 facts in comparison. Accessed 2 july , 2018. https://versus.com/en/athens-vs-london.

(C) 2018 by the authors; licensee MDPI and IFoU, this article is an open access article distributed under the terms and conditions of the Creative Commons Attribution license.

\footnotetext{
${ }^{\mathrm{i}}$ The etymology of the word in Greek is poly (a lot) and katoikia (residence) and indicates the building with multiple apartments where many families reside.

ii Along with Spain, Italy, Portugal and Ireland, according to Allen et al (Housing and Welfare in Southern Europe 2004).

iii Freehold and leasehold constitute types of tenure in the British law.

iv One example is the Community Resilience Framework and is available here: https://www.gov.uk/government/publications/community-resilience-framework-for-practitioners

$v$ The definition of them has been provided in chapter 3 .

vi This tactic refers to investments in property purchases which remain empty until their price rises and a profit is made by their resale.

vii According to the Manager of LRT (2018), the Chalcot estate evacuation was conducted 10 days after the Grenfell fire to ensure the tower block met the fire regulations. This had as a result the displacement of 3,000 people overnight.
} 